\title{
Edukasi Pembuatan Masker Tanpa Mesin Jahit Sebagai Cara Pencegahan Adanya Wabah Virus Corona Bagi Ibu Dasa Wisma Desa Kutasari Baturraden Banyumas
}

\author{
Desty Rakhmawati $^{1)}$, Cahya Giwangkara Yuliawan ${ }^{2)}$, Rizki Nur Armanda ${ }^{3)}$ \\ Universitas Amikom Purwokerto, Indonesia ${ }^{1,2), 3)}$ \\ email: desty@amikompurwokerto.ac.id ${ }^{1)} \underline{\text { cahyagiwangkara27@ @mail.com }}^{2)}$; \\ rizkinurarmanda53@gmail.com_3)
}

\begin{tabular}{l|l|l}
\hline Dikirim: 06-01-2021 & Direvisi: 29-01-2021 & Diterbitkan: 28-02-2021
\end{tabular}

\begin{abstract}
Abstrak
Pada akhir tahun 2019, di Indonesia mulai muncul wabah virus corona. Virus corona adalah virus yang dapat menular ke manusia, baik bayi, anak- anak, orang dewasa, lansia, bahkan ibu hamil dan menyesui dapat terinfeksi virus corona. Ada beberapa aturan yang harus di patuhi dalam pencegahan virus corona. Salah satunya adalah wajib menggunakan masker ketika keluar dari rumah. Akan tetapi ada beberapa warga di Desa Kutasari Kecamatan Baturraden Kabupaten Banyumas, ketika keluar rumah tidak menggunakan masker. Sehingga tujuan dari pengabdian ini, adalah memberikan edukasi terkait virus corona dan cara membuat masker tanpa menggunakan mesin jahit. Sasaran pengabdian ini adalah Ibu Dasa Wisma di Desa Kutasari Kecamatan Baturraden Kabupaten Banyumas Jawa Tengah. Metode yang digunakan adalah memberikan edukasi dan juga memberikan pelatihan membuat masker tanpa menggunakan mesin jahit. Edukasi ini disampaikan melalui media online, yaitu dengan membuatkan video pembuatan masker tanpa mesin jahit yang kemudian di bagikan ke grup WhatsApp Dasa Wisma. Hal ini dikarenakan ketika ada wabah virus corona, ada larangan untuk melakukan kerumunan. Sehingga pengabdian ini dilakukan secara online. Hasil dari program pengabdian ini diantaranya adalah ibu- ibu dapat membuat masker sendiri tanpa menggunakan mesin jahit dan ketika keluar rumah mematuhi protokol kesehatan melalui penggunaan masker.
\end{abstract}

Kata Kunci: Masker, Video, Virus Corona

\begin{abstract}
At the end of 2019, the corona virus outbreak began to emerge in Indonesia. The corona virus is a virus that can be transmitted to humans, both babies, children, adults, the elderly, even pregnant and breastfeeding women can be infected with the corona virus. There are several rules that must be obeyed in preventing the corona virus. One of them is the mandatory use of a mask when leaving the house. However, there are some residents in Kutasari Village, Baturraden District, Banyumas Regency, when they leave the house they don't wear a mask. So that the aim of this service is to provide education related to the corona virus and how to make masks without using a sewing machine. The target of this service is Mrs. Dasa Wisma in Kutasari Village, Baturraden District, Banyumas Regency, Central Java. The method used is to provide education and also provide training to make masks without using a sewing machine. This education is delivered through online media, namely by making videos of making mask without sewing machines which are then distributed to the WhatsApp Dasa Wisma group. This is because when there is a corona virus outbreak, there is a ban on crowds. So that this service is done online. The results of this service program include mothers
\end{abstract}


being able to make their own masks without using a sewing machine and when leaving the house adhere to health protocols through the use of mask.

Kata Kunci: Mask, Video, Corona Virus

\section{PENDAHULUAN}

Desa Kutasari merupakan salah satu desa yang termasuk dalam kecamatan Baturraden, Kabupaten Banyumas, dengan kode postnya adalah 53151. Berdasarkan hasil observasi, bahwa desa Kutasari berada di Kecamatan Baturraden, Kabupaten Banyumas dan letak geografis atau tata letak batas wilayah desa Kutasari disebelah utara adalah desa Pamijen dan desa Pandak, disebelah timur adalah berbatasan dengan kelurahan Pabuaran kecamatan Purwokerto Utara, di sebelah selatan adalah berbatasan dengan desa Purwosari dan kelurahan Sumampir kecamatan Purwokerto Utara. Dan sebelah barat berbatasan dengan desa Beji kecamatan Kedung Banteng. Desa Kutasari terdiri dari 3 Dusun dan 7 RW 36 RT, yaitu Dusun 1 wilayahnya RW 1 RW 2 dan RW 6 Dusun 2 wilayahnya RW 4 dan RW 5, Dusun 3 wilayahnya RW 3 dan RW 7, Grumbul yang ada di Desa Kutasari terdiri dari 4 grumbul yaitu Grumbul Prompong, Grumbul Dukuh Prompong, Grumbul Brobahan dan Grumbul Semingkir.

Pada akhir tahun 2019, di Indonesia mulai muncul wabah virus corona. Virus corona atau dikenal dengan virus 2019 Novel Coronavirus (2019-nCoV) (Huang et al. 2019). 2019nCoV adalah jenis virus yang dapat menular ke manusia, baik bayi, anak- anak, orang dewasa, lansia, bahkan ibu hamil dan menyesui dapat terinfeksi virus corona. Infeksi virus pertama kali di temukan di kota Wuhan, Provinsi Hubei Cina. Infeksi ini muncul pertama kali pada akhir Desember 2019 (Wang et al.). Infeksi dari virus ini disebut dengan COVID-19. Virus Corona merupakan sekumpulan virus yang dapat menginfeksi pada sistem pernapasan. Virus ini menginfeksi pada sistem pernapasan ringan, dan juga dapat menyebabkan infeksi pernapasan berat (Tuti Meihartati, Aries Abiyoga, Dodi Saputra). Infeksi Ringan, dapat menyebabkan penderita mengalami gejala flu seperti hidung berair dan meler, sakit kepala, batuk, nyeri tenggorokan dan demam atau adanya gejala infeksi pernafasan berat seperti infeksi paru-paru (pneumonia), demam tinggi, batuk berdahak bahkan berdarah, sesak nafas, dan nyeri dada. Dan secara umum, tanda- tanda seseorang yang terinfeksi virus corona adalah demam, batuk dan sesak nafas. Gejala COVID-19 muncul dalam waktu 2 hari sampai 2 minggu setelah terpapar virus Corona. Suhu badan seseorang yang memiliki tanda- tanda terinfeksi virus ini adalah sampai diatas $38^{\circ} \mathrm{C}$ (Zulva).

Aturan yang harus di taati ketika adanya wabah virus Corona dengan tujuan perlindungan kesehatan individu seperti menggunakan alat pelindung diri ketika berinteraksi dengan orang lain atau ketika keluar rumah dengan menggunakan masker yang menutupi hidung, dan mulut hingga dagu. Selain itu juga membersihkan tangan secara teratur menggunakan sabun dan air mengalir atau menggunakan handsanitizer, kemudian jaga jarak minimal 1 meter dengan orang lain, serta meningkatkan daya tahan tubuh dengan menerapkan perilaku hidup bersih dan sehat (Permenkes RI KMK No. HK.01.07/MENKES/382/2020). Berdasarkan hasil observasi dan wawancara dengan warga 
Desa Kutasari, khusus nya untuk Dusun Prompong, dalam menghadapi adanya wabah virus corona ini, ada beberapa aturan yang harus di patuhi dalam pencegahan adanya wabah virus corona. Diantara nya adalah wajib menggunakan masker ketika keluar dari rumah, jika batuk, maka tutupi dengan tissue atau lengan baju bagian dalam. Kemudian tidak menyentuh wajah (mata, hidung dan mulut) sebelum mencuci tangan, cuci tangan menggunakan sabun dengan air mengalir sesering mungkin, Menggunakan hand sanitizer pada waktu yang diperlukan. Dan jaga jarak setidaknya maksimal 2 meter dari orang lain (social distancing). Kemudian hasil observasi juga menunjukkan bahwa di Desa Kutasari, ada beberapa yang keluar rumah tidak mengikuti atauran, yaitu ada yang tidak menggunakan masker, meskipun sudah banyak warga yang didepan rumahnya menyediakan air dan sabun untuk mencuci tangan, akan tetapi ada beberapa yang tidak mengikuti aturan untuk menggunakan masker ketika berpergian. Penggunaan masker adalah hal yang wajib yang harus di patuhi di masa pendemi ini, hal tersebut di karenakan Penggunaan masker menjadi salah satu langkah pencegahan yang dapat membatasi penyebaran penyakit- penyakit saluran pernapasan tertentu yang diakibatkan oleh virus, termasuk COVID-19(WHO). (Meri et al.) juga mengungkapkan bahwa tidak hanya penggunaan handsanitizer, tapi masker juga digunakan sebagai upaya preventif terhadap Covid-19, dan bahkan adanya pemberian sanksi sosial oleh Desa Adat ketika tidak menggunakan masker saat berkendara motor di masa pandemic covid-19 (Komang Ratih Kumala Dewi). Begitu pentingnya penggunaan masker di masa pandemi ini, dan masih ada beberapa warga di desa kutasari yang belum menggunakan masker ketika keluar rumah di masa pandemi, dan belum ada sangksi sosial terhadap warga yang tidak menggunakan masker ketika keluar rumah sehingga, pengabdian ini akan memberikan penyuluhan guna mengedukasi terkait degan covid-19 dan pembuatan masker, seperti yang dilakukan oleh (Asnawati et al.) melakukan pengabdian kepada masyarakat berupa penyuluhan dan sosialisadi masker sebagai bentuk kepedulian terhadap masyarakat di tengah mewabahnya virus covid-19, dan (Hastiningsih and Sari) juga melakukan penyuluhan terkait cuci tangan dan juga penyuluhan penggunaan masker di masa pandemi ini. Sehingga pengabdian ini adalah memberi edukasi pembuatan dan penggunaan masker.

Berdasarkan permasalahan tersebut, sehingga suatu solusi untuk menyelesaikan permasalahan di atas, yaitu dengan adanya program pengabdian kepada masyarakat, ini diharapkan akan dapat menyelesaikan permasalahan tersebut. Dimana program pengabdian kepada masyarakat adalah dengan cara memberikan edukasi terkait pentingnya menggunakan masker di saat adanya wabah virus corona dan juga memberikan edukasi terkait cara membuat masker, meskipun tanpa menggunakan mesin jahit. Karena berdasarkan hasil wawancara dengan Ibu Dasa Wisma di Desa Kutasari, tidak memiliki mesin jahit, sehingga edukasi ini diberikan tanpa menggunakan mesin jahit. Dan tujuan pengabdian ini diharapkan ibu- ibu dapat membuat masker sendiri tanpa menggunakan mesin jahit dan ketika keluar rumah mematuhi protokol kesehatan melalui penggunaan masker.

\section{METODE}

Pelaksanaan pengabdian ini dilaksanakan pada hari senin, tanggal 30 November 2020. Yang dimulai dari jam 13.00 WIB sampai dengan 16.00 WIB. Metode yang digunakan dalam 
pengabdian ini adalah dengan cara memberikan edukasi terkait dengan apa itu virus corona, dan pentingnya penggunaan masker serta edukasi cara pembuatan masker beserta dengan connector tanpa menggunakan mesin jahit. Edukasi ini, di transfer ke sasaran pengabdian yaitu Ibu- ibu Dasa Wisma di Desa Kutasari Kecamatan Baturraden Kabupaten Banyumas Jawa Tengah. Edukasi ini dilaksanakan secara online, hal ini dikarenakan di masa pandemic ini dilarang mengadakan kerumunan, sehingga edukasi ini dilakukan secara online. Adapun tahapan dalam proses pengabdian ini adalah 1) Observasi awal sebelum mengadakan pengabdian yaitu untuk melihat penggunaan masker di Desa Kutasari, bahwa di Desa Kutasari khususnya di Dusun Prompong, warga ketika keluar rumah tidak menggunakan masker dan belum ada sanksi apabila tidak menggunakan masker di masa pandemi covid-19. 2) Pelaksanaan pengabdian, dengan cara memberikan edukasi melalui pemberian modul dan diskusi serta memberikan video di grup WhatsApp yang beranggotakan Ibu- ibu dawis. Modul yang diberikan berisi informasi terkait virus corona yang merupakan virus yang sangat berbahaya dan dapat menyerang baik anak anak, dewasa ataupun orang tua. Di modul yang diberikan juga memberikan pengetahuan terkait pentingnya penggunaan masker sebagai pencegahan terinfeksi virus corona. Serta modul juga memberikan tutorial cara membuat masker serta connector tanpa mesin jahit. Kemudian video yang diberikan berisikan cara atau langkah- langkah dalam membuat masker dan connector tanpa menggunakan mesin jahit, 3). Observasi hasil setelah diberikan edukasi, untuk melihat taatnya menggunakan masker. Observasi hasil ini dilakukan setelah pelaksanaan pengabdian yaitu dari tanggal 30 November 2020 sampai dengan 15 Desember 2020. Hasil observasi memperlihatkan adanya pengaruh terhadap warga khususnya untuk ibu-ibu dawis, ketika keluar rumah menggunakan masker. Sehingga mereka lebih mematuhi protokol penggunaan masker di masa pandemi covid-19.

\section{HASIL DAN PEMBAHASAN}

Kegiatan pengabdian yang dilaksanakan secara online melalui grup WhatsApp dengan sasaran adalah ibu- ibu dawis di desa Kutasari, memberikan edukasi yang penting di masa pandemic ini, yaitu sasaran pengabdian dapat membuat masker dan connector nya tanpa menggunakan mesin jahit. Dimana sebelum membuat masker, bahan dan alat harus dipersiapkan terlebih dahulu. Dimana bahan dan alat untuk membuat connector adalah Gunting, Korek Api Gas, Tali kur (100 cm ada 2 warna dan $50 \mathrm{~cm}$ juga 2 warna), Penggaris, Isolasi, Benang Jahit, Jarum Jahit dan Kancing Button (2 kancing). Bahan- bahan dan alatalat yang digunakan untuk membuat masker adalah Pola Masker, Kain Masker (2 Kain berbeda), Tali masker untuk diikat di telinga $(20 \mathrm{~cm})$, Benang Jahit, Jarum Jahit, Gunting, Penggaris. Langkah- langkah pembuatan connector adalah

1. Menyiapkan semua bahan yang digunakan untuk pembuatan connector masker

2. Ambil tali kur dengan warna yang berbeda dimana untuk tali kur ada 4 tali yang sudah di ukur. 2 tali kur dengan warna berbeda berukuran $100 \mathrm{~cm}$ dan 2 tali kur dengan warna yang berbeda pula berukuran $50 \mathrm{~cm}$. Jadikan satu dari 4 tali kur tersebut dimana posisi tali kur yang berukuran $100 \mathrm{~cm}$ berada di ujung dan 2 tali kur yang berukuran $50 \mathrm{~cm}$ di letakkan di 
tengan. Dengan posisi tali kur dengan warna yang berselang seling. Untuk lebih jelas nya dapat dilihat pada Gambar 1. Di bawah ini

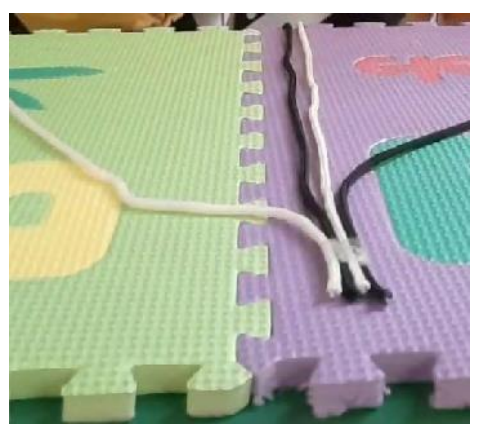

Gambar 1. Posisi Tali Kur dengan Warna yang Berselang Seling

3. Setelah itu memulai dalam membuat pola connector yaitu pada tali kur bagian panjang yang berada di ujung yang warna hitam, di masukkan di bagian bawah dua tali kur yang pendek, lakukan sebanyak dua kali, kemudian bergantian tinggal tali kur yang warna putih yang panjang di masukkan bagian atas dua tali kur yang pendek, lakukan sebanyak dua kali. Begitu seterusnya sehingga akan terlihat seperti Gambar 2. Di bawah ini

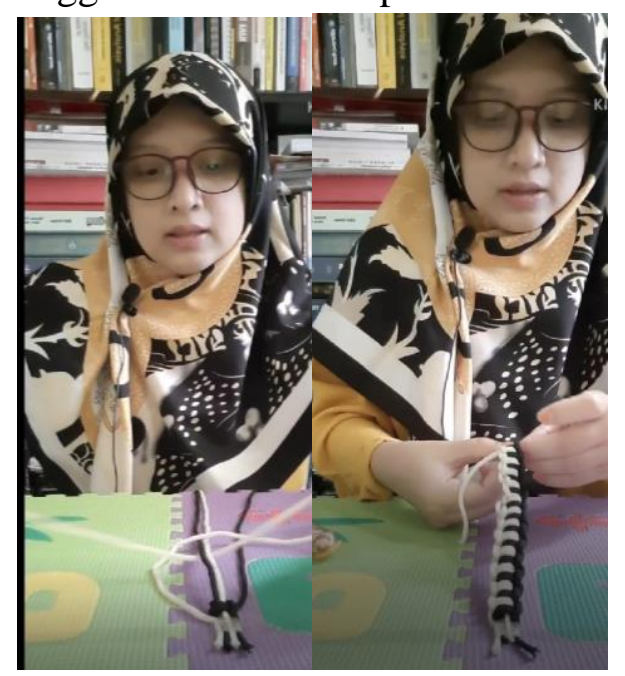

Gambar 2. Tampilan Proses Pembuatan Connector

4. Setelah itu pada bagian ujung connector tersebut, tali kur di gunting dan di rapikan dengan menggunakan api sehingga tidak akan lepas ikatannya. Kemudian beri kancing button pada ujung atas tali kur tersebut yang diikat dengan menggunakan benang jahit, sehingga akan membentuk connector seperti di Gambar 3. Di bawah ini 


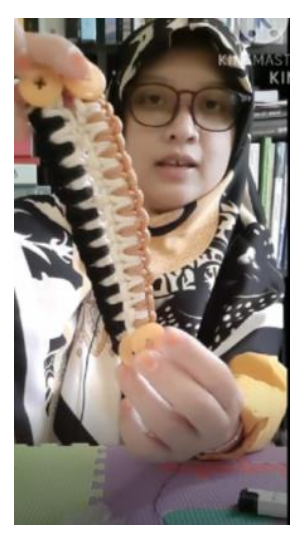

Gambar 3. Tampilan Connector yang Sudah diberikan Kancing Button

Gambar 3. Di atas menggambarkan hasil akhir dari connector, yang sudah siap di pakai. Setelah selesai pembuatan connector dilanjutkan dengan pembuatan masker. Selanjutnya adalah membuat maskernya. Langkah- langkah pembuatan masker pada adalah

1. Menyiapkan semua bahan yang digunakan untuk pembuatan masker

2. Menyiapkan pola masker, dan untuk pola dapat dilihat pada gambar 4 di bawah

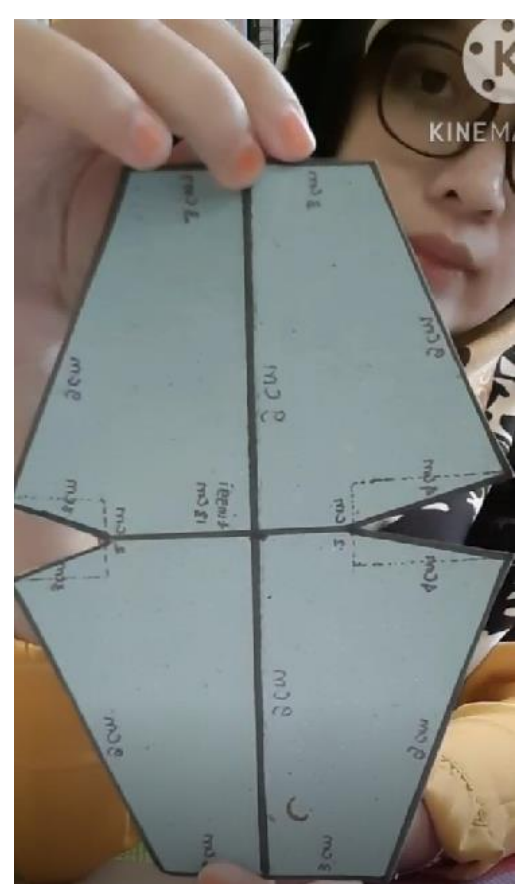

Gambar 4. Pola Masker

Gambar 4, menggambarkan pola masker, dimana garis horizontal dan vertikal panjangnya $18 \mathrm{~cm}$, yang di bagi menjadi dua masing-masing berukuran $9 \mathrm{~cm}$. Kemudian sisi miring ujung-ujung juga memiliki panjang $9 \mathrm{~cm}$, kemudian tepi tengah yang menjorok ke dalam panjangnya $3 \mathrm{~cm}$ dan $4 \mathrm{~cm}$. 
3. Setelah itu siapkan dua kain masker, disini digunakan kain warna hitam dan krem, kemudian potong mengikuti pola pada tahap 2, di atas dengan memberikan tambahan sekitar $5 \mathrm{~cm}$. Dan dapat dilihat pada Gambar 5, di bawah

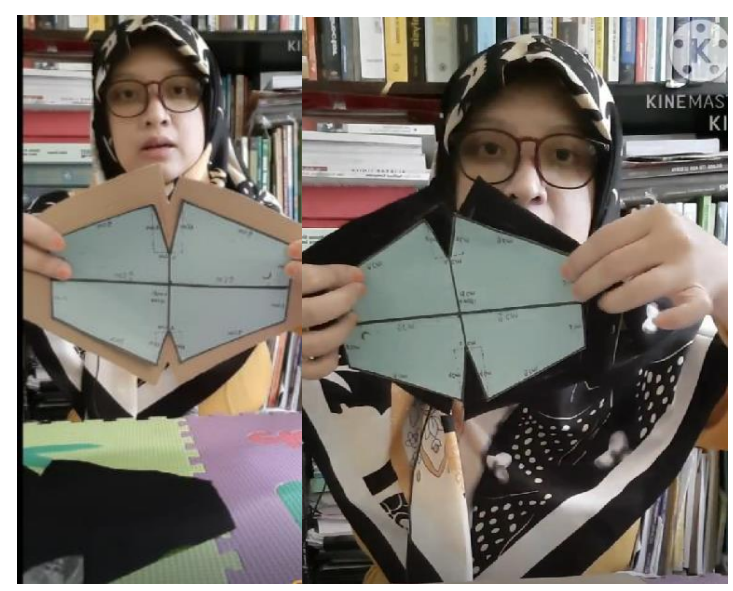

Gambar 5. Pola Kain Masker

4. Setelah itu jahit ke dua kain baik yang warna hitam dank rem, pada bagian samping yang menjorok ke dalam, dan tampilan seperti pada Gambar 6.

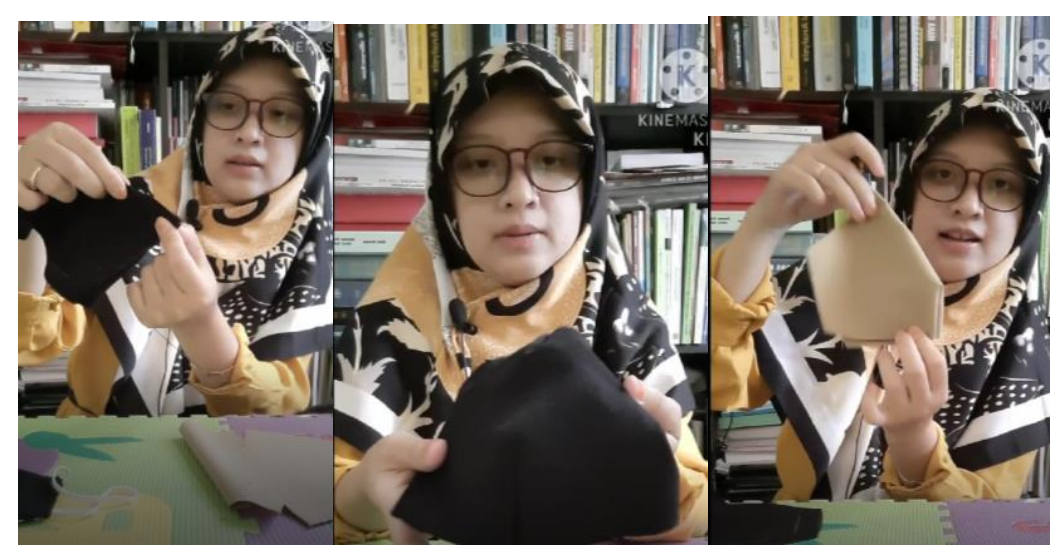

Gambar 6. Tampilan Masker Setelah Bagian Ujung di Jahit

5. Setelah itu gabungkan kain masker warna hitam dan krem sesuai dengan posisi yang sama, kemudian jahitbagian ujung nya, sehingga akan seperti gambar 7 di bawah ini 


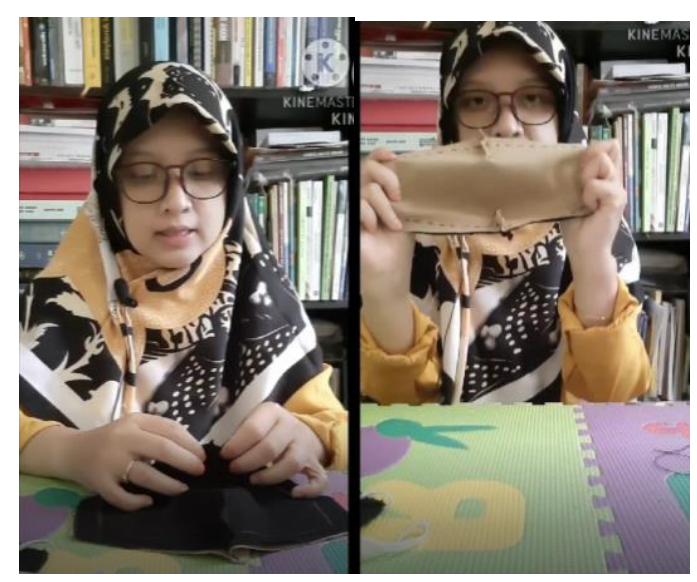

Gambar 7. Tampilan Masker Setelah Bagian Ujung di Jahit

6. Setelah itu baliklah kain yang sudah di jahit sehingga jahitan akan berada di dalam dan tidak terlihat, seperti Gambar 8. Di bawah ini

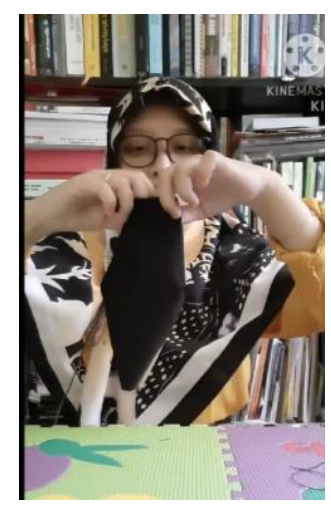

Gambar 8. Tampilan Masker Setelah Jahitan Tidak Terlihat

7. Kemudian pada ke dua ujung samping jahitlah, dengan terlebih dahulu diberikan tali pengait pada telinga, dan tampilan akan seperti Gambar 9 dibawah

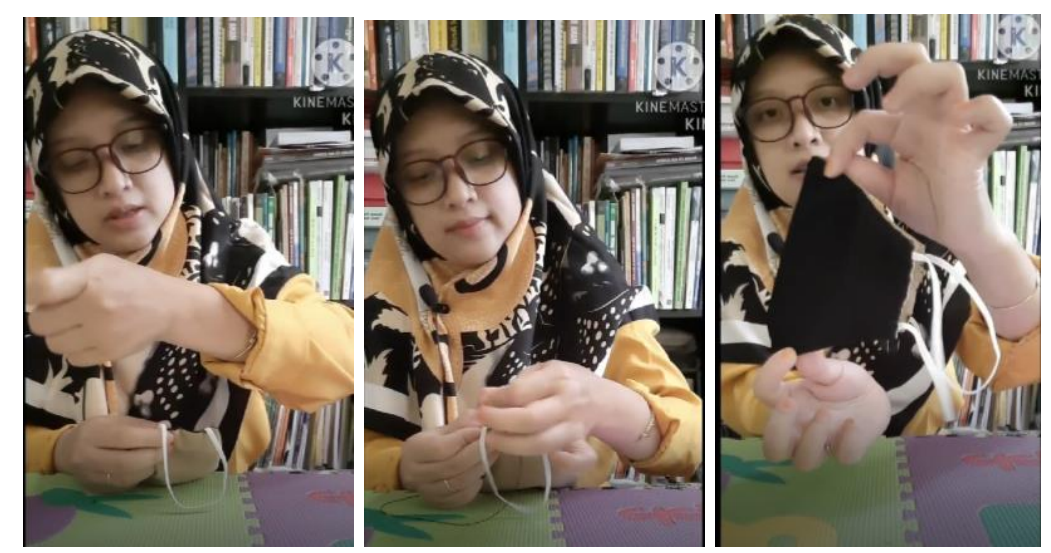

Gambar 9. Tampilan Masker Setelah diberi Tali Pengait Telinga 
8. Setelah masker jadi, lalu dapat digunakan dengan meggunakan connector yang sudah dibuat, dan dapat dilihat pada Gambar 10. Di bawah

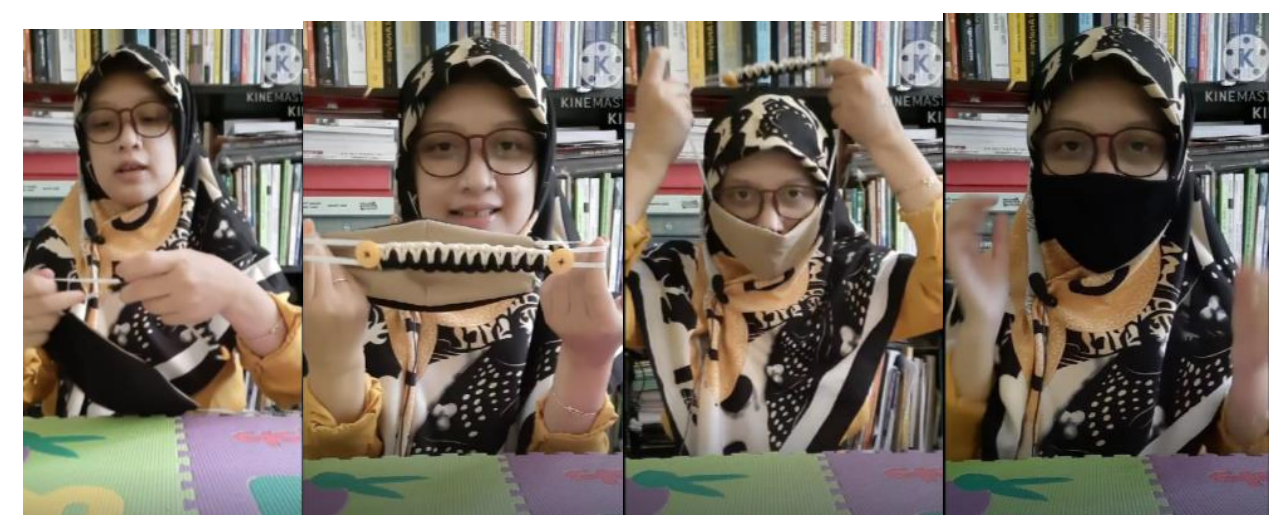

Gambar 10. Tampilan Masker dan Connector yang Siap Pakai

Gambar 10 diatas adalah gambar tampilan masker dan connector yang siap digunakan.

Dan dengan adanya program pengabdian ini, sasaran pengabdian lebih mematuhi protokol penggunaan masker di masa pandemi covid-19. Ketika keluar rumah, sudah menggunakan masker.

\section{SIMPULAN}

Berdasarkan hasil dan pembahasan di atas dapat di simpulkan bahwa, dengan adanya kegiatan pengabdian ini diantaranya adalah 1) Ibu- ibu dasa wisma mendapatkan edukasi terkait dengan virus corona dan pentingnya mematuhi protokol kesehatan. 2) Ibu- ibu dasa wisma mengetahui dan mempraktekkan membuat masker beserta dengan connector tanpa menggunakan mesin jahit. 3) Mematuhi protokol kesehatan di masa pandemic covid-19 yaitu dengan selalu menggunakan masker. Dan kelebihan dari program pengabdian ini adalah mendapatkan pengetahuan sebagai ladang usaha pembuatan masker dan connector yang dapat dijual. Kemudian saran untuk pengembangan pengabdian selanjutnya adalah memberikan edukasi selain kepada ibu- ibu dasa wisma, sehingga akan lebih banyak lagi sasaran pengabdian dan manfaatnya akan di rasakan oleh banyak orang.

\section{UCAPAN TERIMA KASIH}

Penulis mengucapkan terima kasih kepada Universitas Amikom Purwokerto, yang sudah mendanai dalam kegiatan pengabdian kepada masyarakat.

\section{DAFTAR PUSTAKA}

Asnawati, Seri, et al. "Penyuluhan Dan Sosialisasi Masker Di Desa Sifahandro Kecamatan Sawo Sebagai Bentuk Kepedulian Terhadap Masyarakat Ditengah Mewabahnya Virus Covid 19." Jurnal Abdimas Mutiara, vol. 1, no. September, 2020, pp. 115-23.

Hastiningsih, Wahyu Tri, and A. Anditha Sari. "Penyuluhan Penggunaan Masker Dan Cuci Tangan Bagi Pedagang Di Pasar Legi Surakarta." INTEGRITAS : Jurnal Pengabdian, 
vol. 4, no. 1, 2020, p. 82, doi:10.36841/integritas.v4i1.524.

Huang, Chaolin, et al. "Clinical Features of Patients Infected with 2019 Novel Coronavirus in Wuhan, China." The Lancet, vol. 395, no. 10223, 2020, pp. 497-506, doi:10.1016/S0140-6736(20)30183-5.

Komang Ratih Kumala Dewi, Ni. PEMBERIAN SANKSI SOSIAL OLEH DESA ADAT TERHADAP PENGENDARA MOTOR YANG TIDAK MENGGUNAKAN MASKER DI ERA PANDEMI COVID 19. 2020, p. 205.

Meri, et al. "Pemberdayaan Masyarakat Dalam Penggunaan Hand Sanitizier Dan Masker Sebagai Upaya Preventif Terhadap Covid-19." Bantenese - Jurnal Pengabdian Masyarakat, vol. 2, no. 1, 2020, pp. 26-33, doi:10.30656/ps2pm.v2i1.2340.

Permenkes RI KMK No. HK.01.07/MENKES/382/2020. "Corona Virus Disease 2019." Peraturan Menteri Kesehatan Republik Indonesia, vol. Nomor 9, no. Pedoman Pembatasan Sosial Berskala Besar dalam Rangka Percepatan Penanganan Corona Virus DIsease $2019 \quad$ (COVID-19), 2020, pp. http://jurnalrespirologi.org/index.php/jri/article/view/101.

Tuti Meihartati, Aries Abiyoga, Dodi Saputra, Ine Sekar. PENTINGNYA PROTOKOLKESEHATANKELUAR MASUK RUMAH SAAT PANDEMI COVID-19 DILINGKUNGAN MASYARAKAT RT 30 KELURAHAN AIR HITAM, SAMARINDA, KALIMANTAN TIMUR. 2015, pp. 1-27.

Wang, Chen, et al. "A Novel Coronavirus Outbreak of Global Health Concern." The Lancet, vol. 395, no. 10223, 2020, pp. 470-73, doi:10.1016/S0140-6736(20)30185-9.

WHO. "Anjuran Mengenai Penggunaan Masker Dalam Konteks COVID-19." Handbook of Pediatric Retinal OCT and the Eye-Brain Connection, 2019, pp. 285-87, doi:10.1016/B978-0-323-60984-5.00062-7.

Zulva, Tarisa Novita Indana. "Covid-19 Dan Kecenderungan Psikosomatis." Journal of Chemical Information and Modeling, 2020, pp. 1-4, 